Zoologica Poloniae (2012) 57/1-4: 47-64

DOI: $10.2478 / \mathrm{v} 10049-012-0003-4$

\title{
PHYLOGENETIC POSITION OF THE MONOGENEAN MALAYANODISCOIDES BIHAMULI LIM ET FURTADO, 1986 INFERRED FROM SEQUENCE AND SECONDARY STRUCTURE OF 28S rDNA
}

\author{
Anshu Chaudhary* and Hridaya Shanker Singh
}

Molecular Taxonomy Lab, Department of Zoology, Ch. C. S. University, Meerut,250004, India, e-mail: anshu8282@rediffmail.com,

*Corresponding author

\begin{abstract}
The present study is a brief description of the morphology and molecular phylogeny of Malayanodiscoides bihamuli Lim and Furtado, 1986 infecting gill filaments of fish Notopterus chitala (Hamilton). The phylogenetic study was made of $M$. bihamuli and closely related taxa using DNA sequence data obtained from $28 \mathrm{~S}$ rDNA region. Morphology as well as molecular phylogeny strongly supports the establishment of genus Malayanodiscoides and also demonstrates its close relationship with other genera of class Monogenea. In addition, the $28 \mathrm{~S}$ secondary structure model was predicted and found to serve as a useful tool for reconstruction of optimal alignment and can be used as an additional source of data incorporating structural parameters of molecules for the study of phylogeny. Application of the secondary 28S structure data allows a more resolved and realistic picture of relationships. Results also demonstrate the phylogenetic utility of the $28 \mathrm{~S}$ sequence secondary structure data for inferences at higher taxonomic levels.
\end{abstract}

Keywords: Malayanodiscoides, monogenea, 28S rDNA gene, ribosomal DNA, Notopterus chitala

\section{INTRODUCTION}

Genus Malayanodiscoides was established for the worms collected from gill filaments of Notopterus notopterus on the Malaysian peninsula by Lim and Furtado (1986) with M. bihamuli as a type-species. Subsequently, Agrawal et al. 
(1998) described another species under the genus viz., M. indicus from N. notopterus near Lucknow, Uttar Pradesh, India. Lim et al. (2001), on the basis of morphological features, synonymize $M$. indicus Agrawal et al. (1998) with M. bihamuli Lim and FurTADO (1986).

Since its inception, the establishment of the genus has been surrounded with controversies. This genus was differentiated initially from an Ancylocephalid monogenean, Thaparocleidus JAIN (1952) on account of a sac like seminal vesicle and onchium between the first pair of marginal hooks. Presence of such a sclerite is not exclusive to Malayanodiscoides but is also reported from other genera like Bagrobdella Paperna, 1969, Protoancylodiscoides Paperna, 1969, and Bychowskyella Akhmerov, 1952. In addition, this genus was placed, based on the basis of the presence of a sac like seminal vesicle, in the family Ancylodiscoididae, although it is recovered from a Notopterid fish, Notopterus species. Thus, inclusion of this genus in Ancylocephalid has been doubted (LiM et al. 2001).

Morphological characters traditionally used in taxonomy on several occasions are not likely to be informative to infer phylogeny. Besides this, issues of phenotypic plasticity (e.g. convergence), potential flaws of particular morphological characters in their application to phylogenetic inferences which may include character linkage, exceeding interspecific variability, nonhomology, and artifacts in interpreting characters. However, it is found that in monogeneans, the nucleotides contain a sufficient phylogenetic signal to resolve relationships (Olson et al. 2003). Sequences of partial large subunit (28S rDNA) have been successfully used to study phylogenetic relationships of the monogeneans at higher levels (Mollaret et al. 1997, Littlewood et al. 1998, Mollaret et al. 2000b, Jovelin and Justine 2001) and generic levels (Mollaret et al. 2000a, Chisholm et al. 2001, Justine et al. 2002, Olson and Littlewood 2002, Whittington et al. 2004, Wu and Worheide 2005). A general goal of the present work is to develop a phylogenetic framework for Malayanodiscoides Lim and FurTAdo (1986) and to analyze 28S rRNA gene for inferring the phylogenetic position of this genus within the vast class Monogenea.

Moreover, during the study, the secondary structure was predicted for fragments of $28 \mathrm{~S}$ for this species. RNA molecules are key elements in some of the cells most fundamental processes, including catalysis, RNA splicing, and regulation of transcription and translation. To a large degree, the function of a structural RNA molecule is determined by its structure. As ribosomal RNA (rRNA) sequences are highly structured, with large regions exhibiting conserved base pairing patterns, incorporating this information in sequence alignment and tree reconstruction might help to reduce errors associated with these problems (Jow et al. 2002, KJer 2004, Telford et al. 2005, Dohrmann et al. 2006, 2008, Erpenbeck and Worheide 2007, Kjer and Honeycutt 2007, Voigt et al. 2008, VON REUMONT et al. 2009). Since the rRNA molecule forms secondary structures mediated by base pairings, knowledge of secondary structure allows for the application of a more sophisticated model, consequently generating a picture of relationships that is arguably more realistic. 


\section{MATERIALS AND METHODS}

\section{Parasites, DNA extraction and amplification}

Monogenean Malayanodiscoides bihamuli were collected from gills of Notopterus chitala (Hamilton, 1822) near Hastinapur $\left(29^{\circ} 01^{\prime} \mathrm{N}\right.$ and $\left.77^{\circ} 45^{\prime} \mathrm{E}\right)$, Meerut, U.P., India, as per the method suggested by MaLmberg (1970). Morphological studies were made as suggested by Malmberg (1970). For the molecular study, each monogenean was examined with a microscope for species identification and fixed in either $95 \%$ or $100 \%$ ethanol for genomic DNA extraction or destroyed in the process of DNA extraction. Monogenean DNA was extracted from the whole specimen using Qiagen DNeasy Tissue Kit (Qiagen) as per the manufacturer's instructions. 28S rDNA region was amplified with the universal forward primer, (5'-ACCCGCTGAATTTAAGCAT-3') in combination with reverse primer (5'-CTCTTCAGAGTACTTTTCAAC-3'). Each amplification reaction was performed in a final volume of $25 \mu 1$ containing $3 \mu 1$ of lysate, 10X PCR buffer, $1 \mathrm{U}$ Taq polymerase (Biotools), $0.4 \mathrm{mM}$ dNTP and $10 \mathrm{pM}$ of each primer pair in a thermocycler (Eppendorf Mastercycler Personal). PCR amplification was performed using the following conditions: after an initial denaturation at $94^{\circ} \mathrm{C}$ for $3 \mathrm{~min}$, 35 cycles at $94^{\circ} \mathrm{C}$ for $30 \mathrm{sec}$ (denaturation), $56^{\circ} \mathrm{C}$ for $45 \mathrm{sec}$ (annealing), $72^{\circ} \mathrm{C}$ for 10 min (elongation). Resultant PCR products were examined on $1.5 \%$ agaroseTBE gels, stained with ethidium bromide and visualized under ultraviolet light.

\section{DNA sequencing and phylogenetic analyses}

Amplification products were purified by Chromous PCR clean up Kit (\#PCR 10) according to manufacturer's instructions. Gel purified PCR products were sequenced using a Big Dye Terminator version 3.1 cycle sequencing kit in an ABI 3130 Genetic Analyzer with the same primers. Sequences of closely related monogeneans were aligned using the program ClustalW (Thомpson et al. 1994). These are: Bothitrema bothi AF387508; Monocotyle sp. AF387511; Triloculotrema sp. AF387512; Calicotyle affinis AF382061; Pseudodactylogyrus anguillae AJ969950; Pseudodactylogyrus bini AJ969949; Neocalceostoma sp. AF387510; and Thaparocleidus siluri AJ969940. The results of ClustalW analysis is graphically represented by using GeneBee server (Brodsky et al. 1992). Phylogenetic trees were reconstructed using MEGA version 5 (TAMURA et al. 2011). Phylogenetic analyses were performed based on neighbor-joining (NJ) and maximumparsimony (MP) methods. In reconstructing the NJ tree, the Kimura-2-parameter model was used to estimate the distances. To obtain the most-parsimonious tree, the Max-Mini Branch-and-bound search strategy was used in MP method. Robustness of the inferred phylogeny was assessed using a bootstrap procedure with 1,000 replications.

\section{Prediction of secondary structures}

RNA secondary structure was determined using Sfold (Software for Statistical Folding and Rational Design of Nucleic Acids) in the Sribo program based on a statistical sample of Boltzmann ensemble for secondary structures (DiNG 
and LAWRENCE 2003). Subsequently, inferred structure was examined for stems, loops, and bulges. Since GC content is known to influence structural energy, GC percentage was determined using GC calculator (http://www.genomicsplace.com/ gc_calc.html). All non-DNA characters were striped before computing. Energy levels of presumptive secondary structure were then calculated with Mfold (JAEGER et al. 1989, ZUKER et al. 1999). 28S sequences with secondary-structure formats of M.bihamuli and T. siluri were aligned using the MARNA web server (Siebert and BACKOfEn 2005) based on both the primary and secondary structures.

\section{RESULTS}

Malayanodiscoides bihamuli Lim and FuRTADo, 1986

Host- Notopterus chitala (Hamilton, 1822)

Locality- Hastinapur, $\left(29^{\circ} 01^{\prime} \mathrm{N}\right.$ and $\left.77^{\circ} 45^{\prime} \mathrm{E}\right)$, Meerut, U.P., India

Site of infection- Gills

The 108 slides were deposited in the museum of the Department of Zoology (Voucher number HS/Monogenea/2009/08), Ch. C.S. University, Meerut, U.P., India. $298 \mathrm{bp}$ fragment of $28 \mathrm{~S}$ rDNA gene sequence of Malayanodiscoides bihamuli obtained in this study was deposited in GenBank under the accession number GU830882.

\section{Morphology}

Body elongated with a narrow anterior end and broad posterior end measuring $200-250 \times 30-35 \mu \mathrm{m}$. Cephalic region is equipped with four pairs of head organs and two pairs of eye spots along with scattered accessory granules. Pharynx round measuring 15-12 $\mu \mathrm{m}$. Oesophagus very short, intestinal caeca united and crura confluent posteriorly, anterior to the haptor. Ovary is elongated oval, post-equatorial, ventral, intercaecal measuring 45-50 x 15-20 $\mu \mathrm{m}$. Vagina 5-10 $\mu \mathrm{m}$ long, dextral, funnel shaped which leads to ootype complex through vaginal tube. Vitelline glands are densely distributed through out the body, from behind the pharynx up to haptor. Testis measures $25-30 \times 10-20 \mu \mathrm{m}$ single, pear-shaped, intercaecal, pre-equatorial, pre-ovarian. Vas deferens arises from anterior end of testis, loops between intestinal caeca, dilate to form a pear-shaped seminal vesicle which opens at base of copulatory organ. Male copulatory complex comprises of a tube which tapers and ends in a hook measuring 50-55 $\mu \mathrm{m}$ in length. Tube has a bulbous structure in middle region, a broad flat accessory piece. Opisthohaptor is distinctly set off from the body proper, round structure. Armature of the haptor comprised of dorsal and ventral anchors, dorsal and ventral bars and seven pairs of marginal hooklets. Dorsal anchors, inner length 40-45 $\mu \mathrm{m}$, outer length 43-45 $\mu \mathrm{m}$, inner root long 20-25 $\mu \mathrm{m}$, outer root 4-7 $\mu \mathrm{m}$, length of patches $50-10 \mu \mathrm{m}$, recurved point $\mu \mathrm{m}$ long. Ventral anchors, inner length 35-40 $\mu \mathrm{m}$, outer length 40-45 $\mu \mathrm{m}$, inner root 15-20 $\mu \mathrm{m}$ long, outer root 3-5 $\mu \mathrm{m}$, recurved point 15-20 $\mu \mathrm{m}$ long. Dorsal and ventral bar "V" shaped 30-35 $\mu \mathrm{m}$ and 35-40 $\mu \mathrm{m}$ in length respectively. Well developed sleeve 
sclerite is found at the shaft of dorsal and ventral anchors. Marginal hooklets are 7 pairs, of which pair no. 1 measures $15-20 \mu \mathrm{m}$, ventral hooks pair no. 7 with boat shaped bar measures 20-25 mm and five pairs similar, 15-20 $\mu \mathrm{m}$. Comparison of various body parts is given in the table 1 .

Table.1 Comparative measurements of Malayanodiscoides bihamuli.

\begin{tabular}{|c|c|c|}
\hline Body features & $\begin{array}{l}\text { AGRAWAL, VISHWAKARMA } \\
\text { \& GAUR, } 1998 \text { (in } \mu \mathrm{m})\end{array}$ & $\begin{array}{l}\text { Present specimen } \\
\text { (in } \mu \mathrm{m} \text { ) }\end{array}$ \\
\hline \multicolumn{3}{|l|}{ Body: } \\
\hline Length & $430-770$ & $0.200-250$ \\
\hline Width & - & $30-35$ \\
\hline Pharynx & $40-45$ & $15-20$ \\
\hline \multicolumn{3}{|l|}{ Haptor: } \\
\hline Length & - & $45-50$ \\
\hline Width & - & $40-45$ \\
\hline \multicolumn{3}{|l|}{ Dorsal anchor: } \\
\hline Inner length & $35-50$ & $40-45$ \\
\hline Outer length & $38-55$ & $43-45$ \\
\hline Inner root & $18-30$ & $20-25$ \\
\hline Outer root & $2-5$ & $4-7$ \\
\hline Recurved point & $25-35$ & $20-25$ \\
\hline Patch & $5-10$ & $5-10$ \\
\hline \multicolumn{3}{|l|}{ Ventral anchor: } \\
\hline Inner length & $30-40$ & $35-40$ \\
\hline Outer length & $35-45$ & $40-45$ \\
\hline Inner root & $12-25$ & $15-20$ \\
\hline Outer root & $1-4$ & $3-5$ \\
\hline Point & $15-35$ & $15-20$ \\
\hline Dorsal bar & $30-45$ & $30-35$ \\
\hline Ventral bar & $30-50$ & $35-40$ \\
\hline Hooks & $10-25,10-30,15-25$ & $20-25,15-20,15-20$ \\
\hline \multicolumn{3}{|l|}{ Testis: } \\
\hline Length & - & $25-30$ \\
\hline Width & - & $10-20$ \\
\hline Copulatory complex & $48-55$ & $50-55$ \\
\hline \multicolumn{3}{|l|}{ Ovary: } \\
\hline Length & $60-84$ & $45-50$ \\
\hline Width & - & $15-20$ \\
\hline Vagina & - & $5-10$ \\
\hline
\end{tabular}

\section{Phylogenetic Analysis}

Amplified sequence of 28S rDNA of Malayanodiscoides bihamuli is 298 bp long. Analysis with ClustalW shows alignment of M. bihamuli and other monogenean genera individually (Fig. 1). The multiple sequence alignments exhibit the variation in the alignment very clearly. The smallest K2P distance 


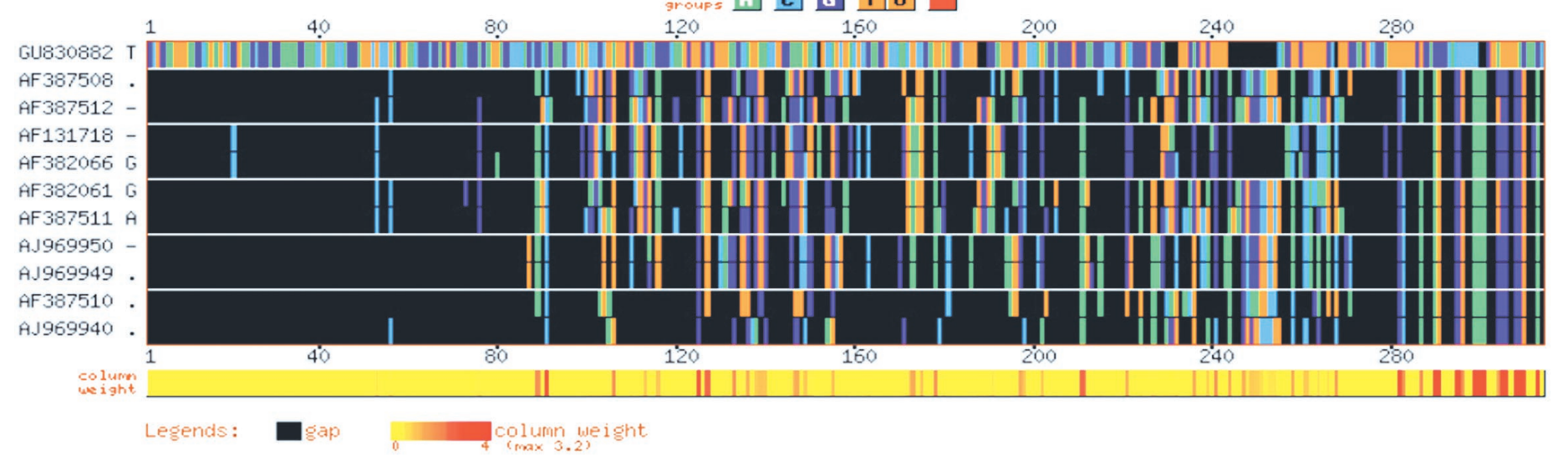

Fig. 1 Alignment of $28 \mathrm{~S}$ sequences of monogenean species.

Table.2 Estimates of evolutionary divergence between sequences using the Kimura 2-parameter model.

\begin{tabular}{|c|c|c|c|c|c|c|c|c|c|}
\hline & GU830882 & AJ969940 & AF387510 & AJ969950 & AJ969949 & AF387508 & AF382061 & AF387511 & AF387512 \\
\hline \multicolumn{10}{|l|}{ M. indicus GU830882 } \\
\hline T. siluri AJ969940 & 0.17 & & & & & & & & \\
\hline$N$. sp. AF387510 & 0.19 & 0.16 & & & & & & & \\
\hline P. anguillae AJ969950 & 0.33 & 0.24 & 0.21 & & & & & & \\
\hline P. bini AJ969949 & 0.34 & 0.25 & 0.21 & 0.01 & & & & & \\
\hline B. bothi AF387508 & 0.34 & 0.27 & 0.27 & 0.30 & 0.31 & & & & \\
\hline C. affinis AF382061 & 0.36 & 0.23 & 0.28 & 0.28 & 0.29 & 0.25 & & & \\
\hline M. sp. AF387511 & 0.38 & 0.24 & 0.28 & 0.28 & 0.29 & 0.27 & 0.12 & & \\
\hline T. sp. AF387512 & 0.40 & 0.27 & 0.31 & 0.30 & 0.31 & 0.25 & 0.10 & 0.12 & \\
\hline
\end{tabular}


(0.17) was found between sequence of M. bihamuli and Thaparocleidus siluri (AJ969940), the longest between M. bihamuli and Triloculotrema sp. (AF387512) as shown in Table 2. Both NJ and MP analysis inferred from 28S rDNA sequences gave similar topology, thus only the NJ phylogenetic tree is given (Fig. 2). Bootstrap values below $50 \%$ were not consider. The most important finding is that $M$. bihamuli clustered in the same clade with Thaparocleidus in both analyses. In addition, in the NJ and MP tree, M. bihamuli is found to be closest to T. siluri (Zandt, 1924), the species of the genus Thaparocleidus Jain, 1952 (Fig. 2).

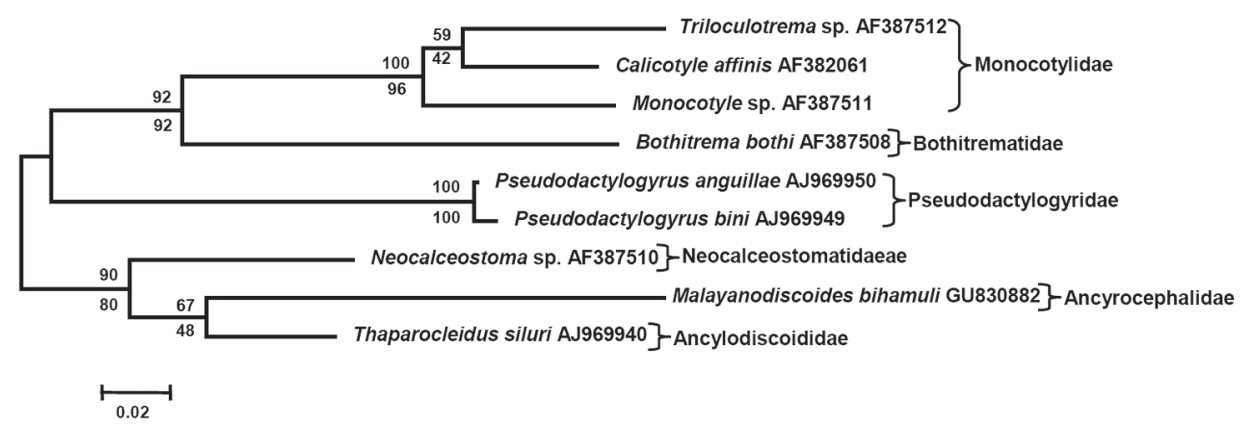

Fig. 2 Neighbor Joining (NJ) bootstrap consensus tree inferred by MEGA 5 for Malayanodiscoides bihamuli based on $28 \mathrm{~S}$ rDNA. The NJ tree was obtained by the bootstrap method with 1000 heuristic search replicates. Bootstrap values are shown at the nodes: NJ and MP values are shown above and below the nodes, respectively.

\section{Secondary structure prediction}

GC content of $28 \mathrm{~S}$ rDNA fragment of the monogenean, M. bihamuli is $46.6 \%$. With the help of primary sequences, the secondary structure is drawn (Fig. 3). In this figure, each residue is shown by a base pair, the hydrogen bonds and backbone of the rRNA secondary structure presented as dots in between the base pair. The highest negative free energy is $-98.00 \mathrm{Kcal}$. Moreover, it shows that the five different types of loops are present i.e., exterior, hairpin, multi, interior and bulge (Fig. 4). Centroid structure of M. bihamuli has also been worked out, showing minimum total base-pair distance (Fig.5). Analysis of this centroid shows an absence of intersecting lines, which proves that pseudoknots are absent in the secondary structure. Besides this, secondary structure of $M$. bihamuli base pair frequencies are nearly similar in the two dimensional histogram (Fig. 6).

The 3D energy landscape plot of the secondary structure of $M$. bihamuli rRNA (Fig. 7) exhibits the presence of two optimal numbers of clusters displayed with the help of red and blue colored dots. Minimum free energy (MFE) structure and ensemble centroid, light blue in color, form the largest cluster with a 


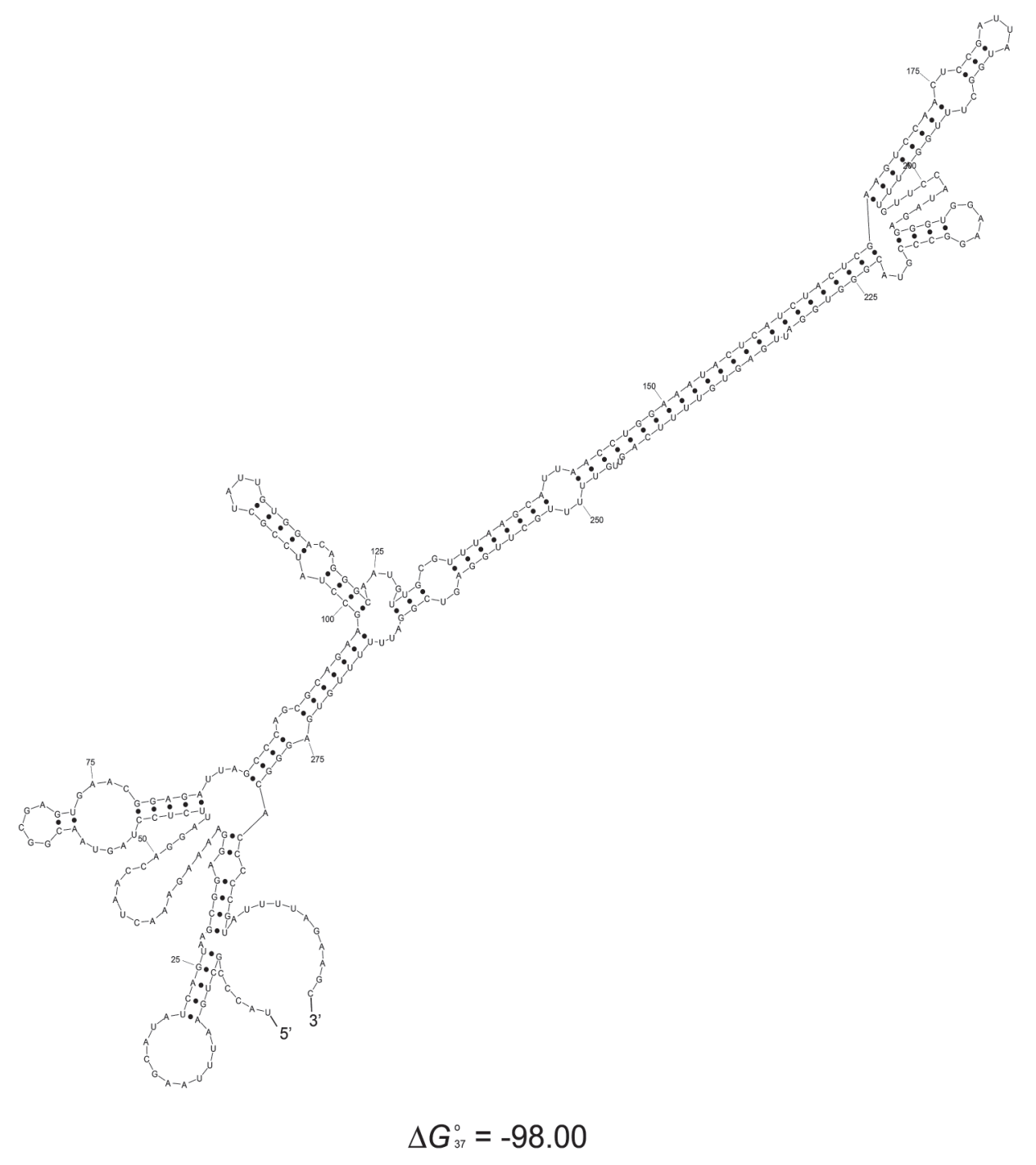

Fig. 3 Predicted 28S RNA secondary structure and their structure formation enthalpy. 


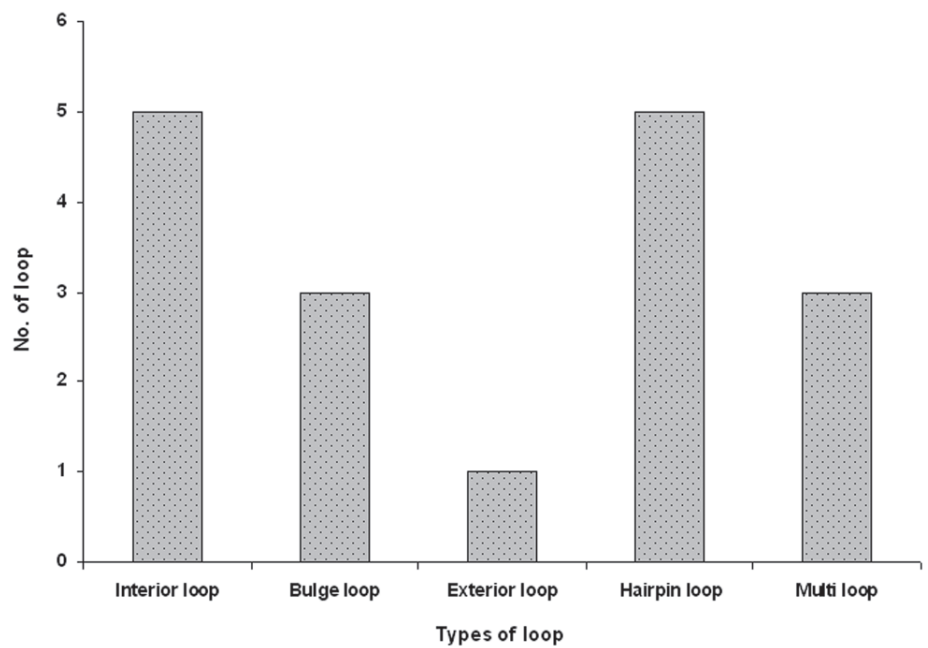

Fig. 4 Distribution of different types of loops of Malayanodiscoides bihamuli large subunit sequence $28 \mathrm{~S}$.

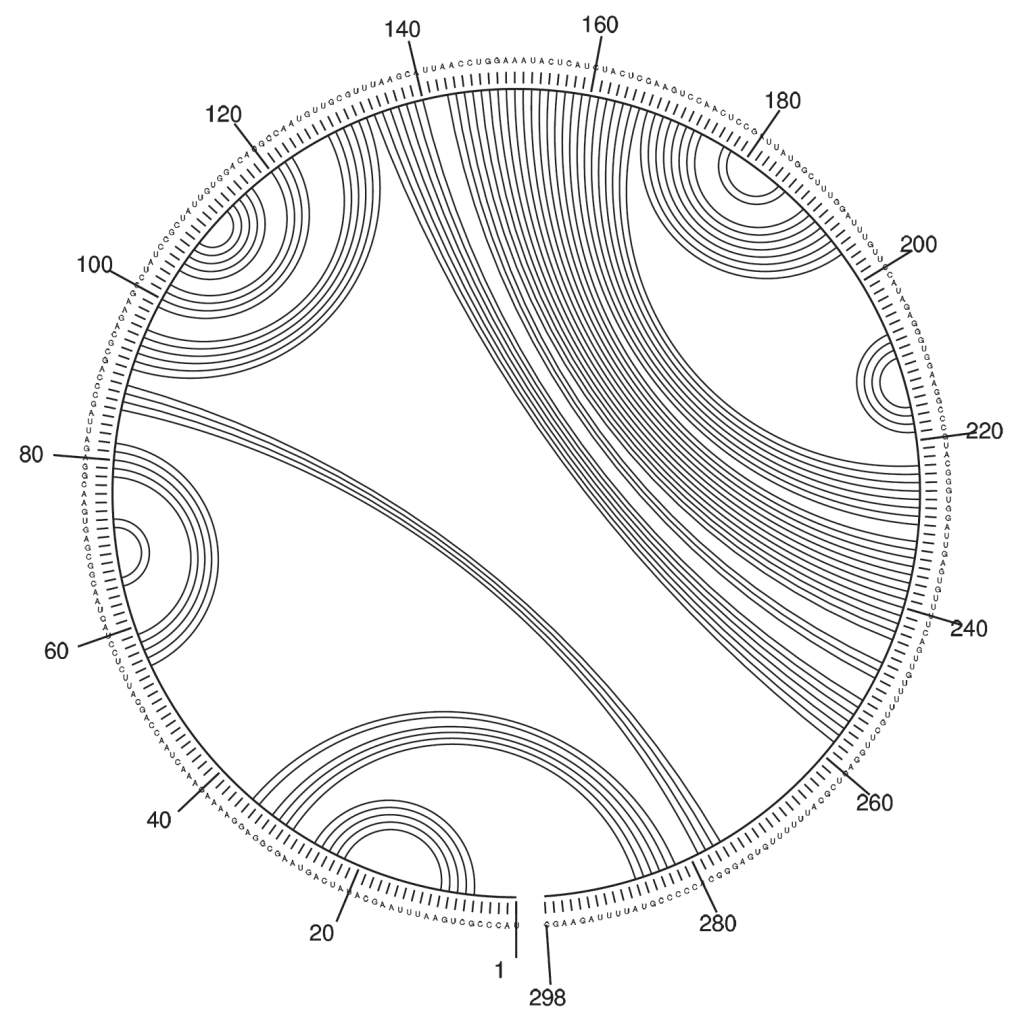

Fig. 5 Centroid for the $28 \mathrm{~S}$ rDNA sequence. 


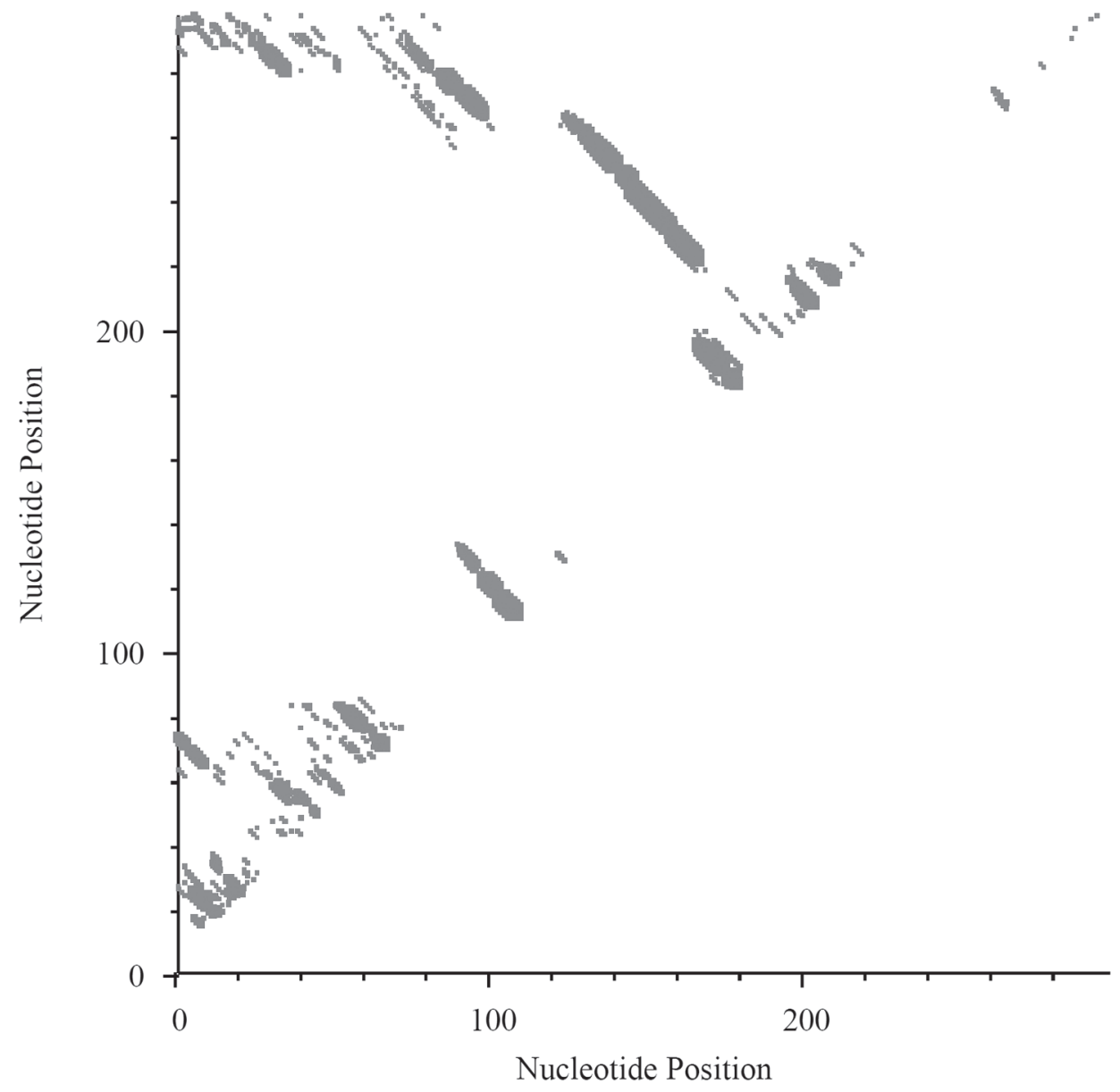

Fig. 6 2D histogram of base pair frequencies of the predicted secondary structure.

probability of 0.681 . The coordinates are given for the MFE structure (-19.16, $16.93,-98.30)$, the ensemble centroid $(-6.05,7.21,-90.90)$, the centroid of cluster $1(-13.99,7.92,-96.90)$, and the centroid of cluster $2(26.68,8.16,-86.24)$.

Reconstruction of optimal alignment using secondary structure information of $M$. bihamuli and $T$. siluri $28 \mathrm{~S}$ sequences were made (Fig. 8). The consensus structure is as a string of dots and brackets on top of the alignment. Compatible base pairs are colored. The hue shows sequence conservation of the 


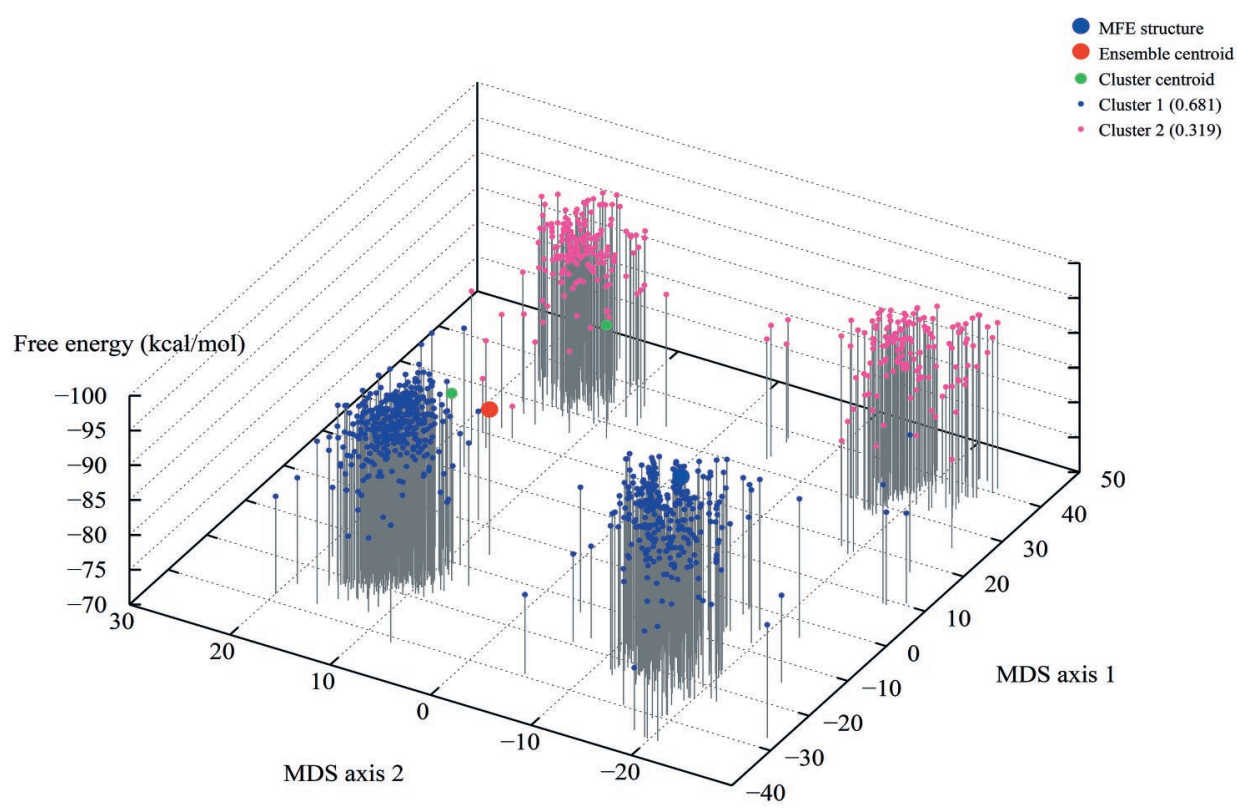

Fig. $73 \mathrm{D}$ energy landscape plot. Cluster size is according to the descending order of clusters and red asterisk shows the cluster containing MFE structure.

base pair. The alignment is shown together in the form of the predicted consensus structure because the accuracy of secondary structure prediction from single species sequences is limited, the consensus structure is formed from the related RNA sequences (Fig. 9). The presence and absence of stems and loops are therefore good phylogenetic indicators for relatively closely related taxa. Considering our findings, the presence and absence of these structures appears to provide strong phylogenetic information at taxonomical levels. We reported the secondary structure of a monogenean $28 \mathrm{~S}$ rDNA sequences and suggest that these predictions of secondary structures that are specific for some monogeneans may be in structures of all diverging monogeneans. Relating secondary structure to sequence information will allow the phylogenetic signal of the large numbers of $28 \mathrm{~S}$ rRNA sequences of monogenea that are currently available in Genbank to be considerably increased. 28S rDNA secondary structures will facilitate the inclusion of secondary structure information in phylogenetic analyses. 


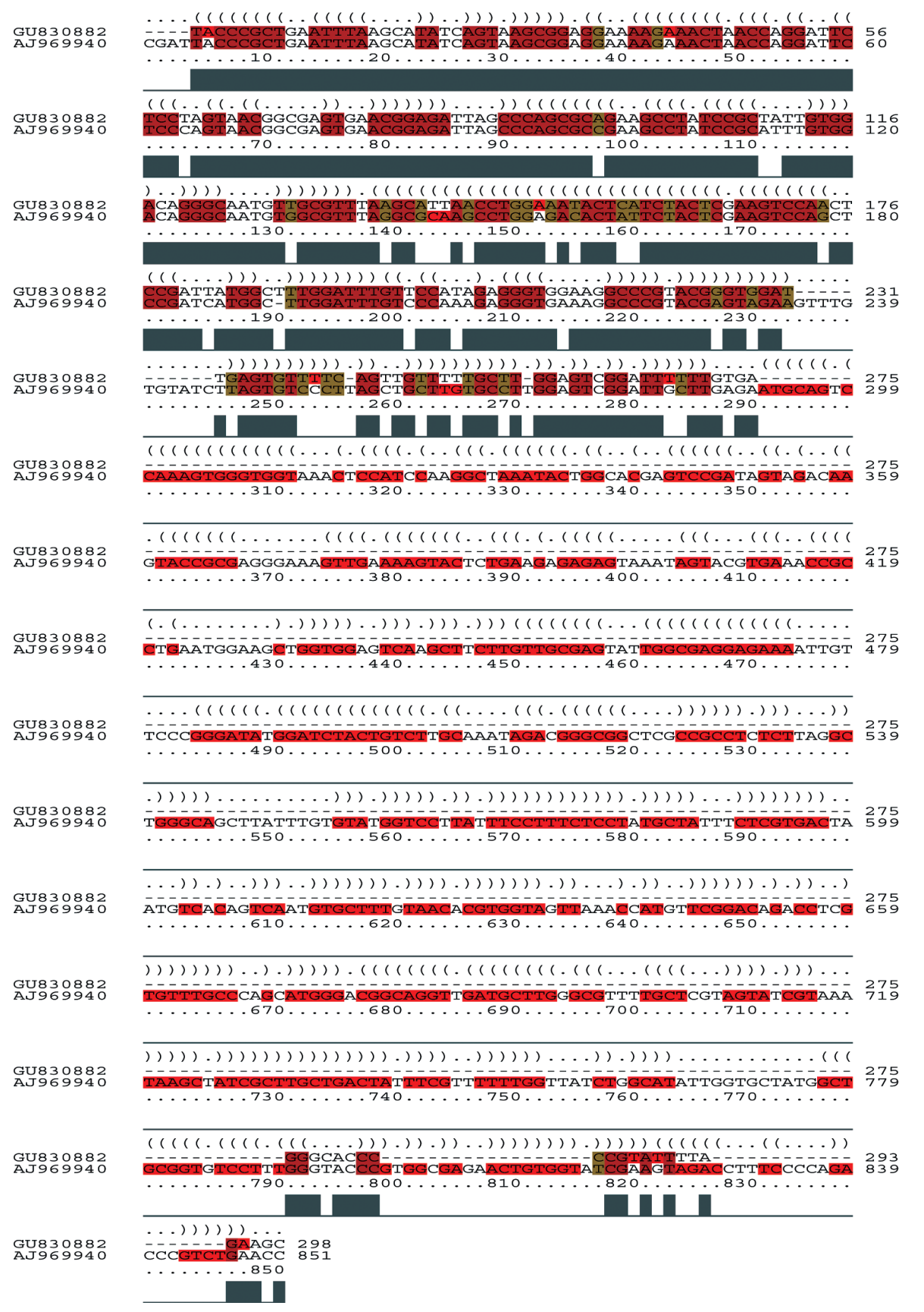

Fig. 8 Alignment with color annotation showing conservation of base pairs and annotated column identity between Malayanodiscoides and T. siluri (Base pairs are colored using the same color code, such that the hue shows sequence conservation and saturation shows structural conservation). 


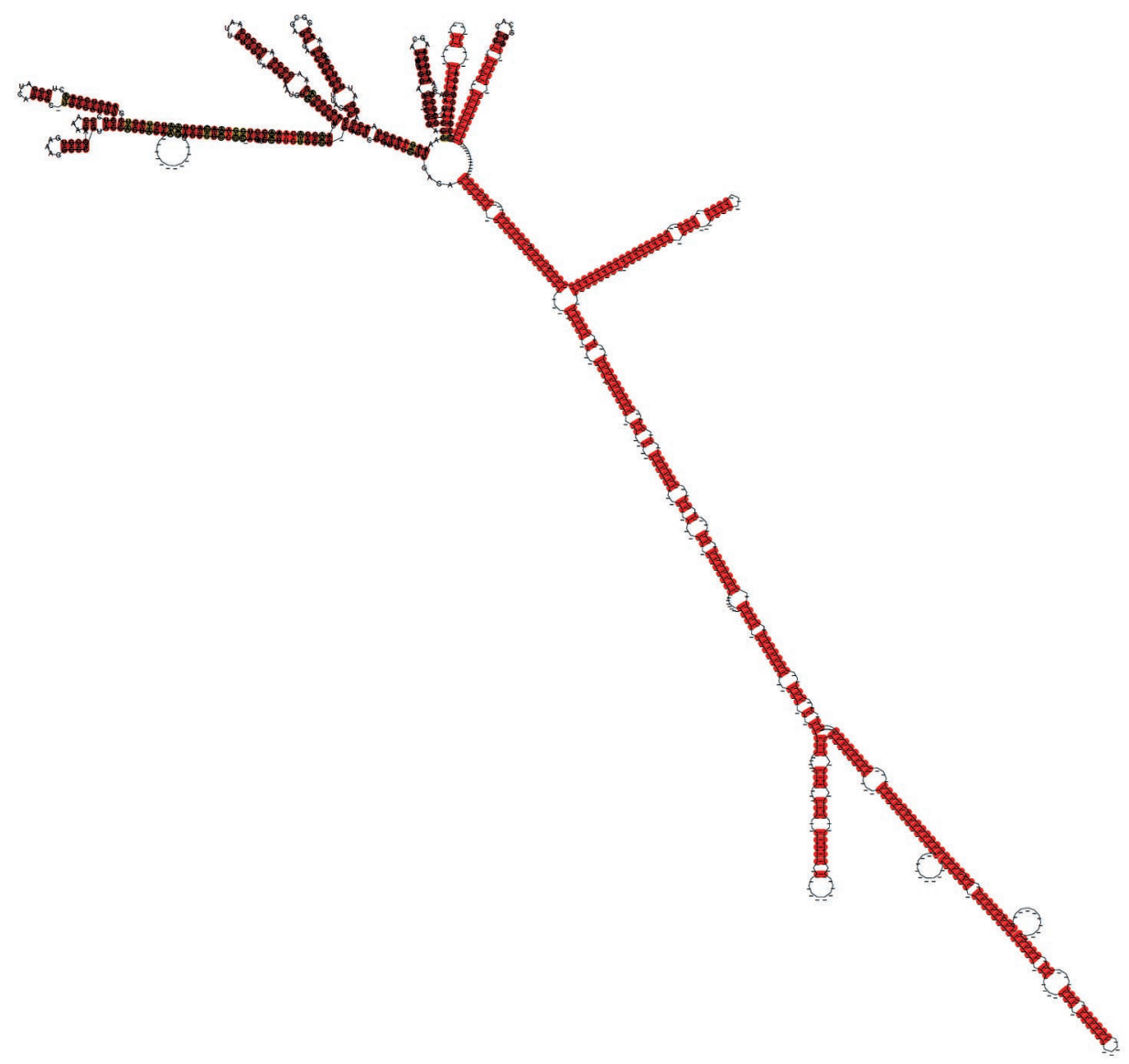

Fig. 9 Consensus secondary structure predicted from figure 8 (same color scheme has been used).

\section{DISCUSSION}

Taxonomic position of M. bihamuli Lim and FurTado, 1986 is based on only morphological features. Moreover, inclusion of this genus in Ancylocephalid has been doubted (Lim et al. 2001). In the present work, M. bihamuli phylogenetic sequence analysis and derived tree topology show a close relationship with the genus Thaparocleidus Jain, 1952 from which it was initially differentiated morphologically. This confirmed the description of new genus Malayanodiscoides by Lim and FurTado (1986). Both the taxa show the formation of the one clade from which, the two species M. bihamuli and T. siluri (ZANDT, 1924) formed separate subclades and confirmed the establishment of species $M$. bihamuli by Lim and Furtado (1986) which is in agreement with the findings of Mollaret et 
al. (2000b), Chisholm et al. (2001), Justine et al. (2002), Olson and Littlewood (2002), Whittington et al. (2004) and Wu et al. (2005) that sequences of 28 rDNA have been successfully used to study phylogenetic relationships. However, the NJ or MP analysis of both species show a close relationship as they did not show high bootstrap values. Therefore, during the study, a new approach is applied in which the measurable structural parameters of the molecules are also used in the form of secondary structure. ZUKER (1994) is of the opinion that secondary structures inferred from the sequence of nucleotides, using energy minimization, provide additional information for species identification.

RNA molecules have versatile functions inside a cell ranging from catalytic processes to complex patterns in gene regulation (FEDOR and Williamson 2005, Amaral et al. 2008, Sharp 2009). During the study, it was found that for monogeneans systematics, RNA secondary structures can be used as an important tool for the differentiation of species because in comparison to primary sequences, the secondary structure contains more information in the form of stems, loops, and minimum free energy (MFE). Little is known about the function and the secondary structure of monogeneans 28S SRNA. Free energy minimization is computed for a specific, selectable temperature. A study by Armbruster (2001) showed slight alterations of the temperature can have a strong influence on the prediction of structure. The minimum free energy is estimated by summing individual energy contributions from base pair stacking, hairpins, bulges, internal loops, and multi-branch loops. The RNA secondary structure consists of stems and loops. Moreover, MDS (multidimensional scaling) is a technique for representing high-dimensional objects in typically two dimensions (KRUSKAL and WiSh 1977). In RNA secondary structures, base pair distances are used as an input to MDS, and members of all other clusters are plotted as small circles (CHAN et al. 2005). RNA molecular structure helps to elucidate an understanding of their functions. A common structure that is conserved is expected when the RNA structure is under selective pressure (BERNHART and Hofacker 2009). The consensus structure is found to be closely linked with molecular functions, so the prediction of these structures is very useful in evolutionarily conserved RNA molecules. The structure prediction method we propose presents a promising approach to reconstruct secondary structures of the $28 \mathrm{~S}$ gene in monogeneans that have not been studied so far. The consideration of taxon specific predicted secondary structures helps to improve the inference of phylogenetic relationships and can provide more realistic values of tree robustness.

In the future, this study needs to be elaborated in order to form a better understanding of the systematics of parasites as well as their evolutionary processes. Earlier studies such as Jow et al. (2002), KJER (2004), TElford et al. (2005), Dohrmann et al. (2006, 2008), Erpenbeck et al. (2007), KJer and Honeycutt (2007), Voigt et al. (2008) and von Reumont et al. (2009) also applied the approach of ribosomal DNA to study mammalian evolution, insect phylogeny, phylogeny of bilateria, phylogeny and evolution of sponges, phylogeny of 
eutheria, molecular evolution of metazoans, and phylogenetic association of arthropods, respectively. In phylogenetic studies involving secondary-structure analysis as a tool, RNA folding is used for refining the alignment. The molecules measurable structural parameters are used directly as specific characters to construct a phylogenetic tree. Molecular morphometrics has been found to be one of the most powerful tools in comparison to classical primary sequence analysis because in the study of phylogenetics, only the size variations of homologous structural segments are considered, whereas molecular morphometrics infers the folding pattern of an RNA molecule. Therefore, with the help of this, homologous recognizable characters are easily seen by finding the same pattern in the secondary structures, as also advocated by PRASAD et al. (2009). Application of the secondary structure model of rRNA to phylogenetic analyses leads to trees with resolved relationships among clades and probably eliminates some artifactual support for misinterpreted relationships. The highly resolved topology in parts of the tree suggests that a deep phylogenetic signal has been retained in the $28 \mathrm{~S}$ sequences of extant species. However, incorporating secondary structure information allows improved estimates of phylogeny among monogenean species. The present identification of the M. bihamuli species with $28 \mathrm{~S}$ sequence and secondary structure analysis is consistent with investigations made using traditional approaches, i.e. by morphology. RNA secondary structure analysis could be a valuable tool because the secondary structure contains more information than the usual primary sequence alignment.

\section{Acknowledgements}

Special thanks to the Department of Zoology, Ch. C. S. University, for resources. Funding for this study was partially supported by grants from the UGC (University Grants Commission), India, under the Post Doctoral Fellowship to $\mathrm{AC}$ and by the Uttar Pradesh Government, Centre of Excellence, India, to HSS, wide project number (No.1486/70-4-2011-46(43)/2010).

\section{POZYCJA FILOGENETYCZNA PRZYWR MONOGENICZNYCH MALAYANODISCOIDES BIHAMULI LIM ET FURTADO, 1986 NA PODSTAWIE SEKWENCJI I STRUKTURY DRUGORZĘDOWEJ REGIONU 28S RDNA}

\section{STRESZCZENIE}

W niniejszych badaniach przedstawiono opis morfologii i filogenezy przywry monogenicznej Malayanodiscoides bihamuli Lim and Furtado, 1986 pasożytującej na skrzelach ryby (nożowiec) Notopterus chitala (НамiLton). Analiza filogenetyczna opierała się o dane sekwencji regionu 28S rDNA. Rezultaty analizy molekularnej oraz morfologicznej potwierdzają przynależność rodzaju Malayanodiscoides i blisko spokrewnionych rodzajów do Monogenea. Ponadto wykazano wysoką wartość diagnostyczną regionu 28S rDNA w badaniach filogenetycznych i taksonomicznych tej grupy. 


\section{REFERENCES}

Agrawal N., Vishwakarma P., Gaur K. 1998: First record of the genus Malayanodiscoides Lim \& Furtado, 1986, from Notopterus notopterus (Pallas) in Lucknow, India. Journal of Parasitology and Applied Animal Biology, 7: 93-96.

Aкhmerov A.Кн. 1952: New species of monogenetic trematodes of Amur fish. Parazitologicheskii Sbornik, 14: 181-212.

Amaral P.P., Dinger M.E., Mercer T.R., Mattick J.S. 2008: The eukaryotic genome as an RNA machine Science, 319: 1787-1789.

Armbruster G.F.J. 2001: Temperature-based variation of rRNA secondary structure models: a case study in the insect Drosophila simulans, the land snail Isabellaria adriani, and the crustacean Daphnia pulex. Canadian Journal of Zoology, 79: 334-345.

Bernhart S.H., Hofacker I.L. 2009: From consensus structure prediction to RNA gene finding. Briefings in Functional Genomics, 8: 461-471.

Brodsky L.L., Vassilyev A.V., Kalaydzidis Y.L., Osipov Y.S.,Tatuzov Y.R.L., Feranchuk S.I. 1992: GeneBee: the program package for biopolymer structure analisis. Dimacs, 8: $127-139$

Chan C.Y., Lawrence C.E., Ding Y. 2005: Structure clustering features on the Sfold Web server. Bioinformatics, 21: 3926-3928.

Chisholm L.A., Whittington I.D., Morgan J.A.T., Adlard R.D. 2001: The Calicotyle Conundrum: Do Molecules Reveal More Than Morphology? Systematic Parasitology, 49: 81-87.

Ding Y., LAwrence C.E. 2003: A statistical sampling algorithm for RNA secondary structure prediction. Nucleic Acids Research, 31: 7280-7301.

Dohrmann M., Janussen D., Reitner J., Collins A., Wörheide G. 2008: Phylogeny and evolution of glass sponges (Porifera: Hexactinellida) Systematic Biology, 57: 388-405.

Dohrmann M., Voigt O., Erpenbeck D., Wörheide G. 2006: Non-monophyly of most supraspecific taxa of calcareous sponges (Porifera, Calcarea) revealed by increased taxon sampling and partitioned Bayesian analysis of ribosomal DNA. Molecular Phylogenetics and Evolution, 40: 830-843.

Erpenbeck D., Wörheide G. 2007: On the molecular phylogeny of sponges (Porifera) In: Zhang Z-Q, Shear WA, editors. Linnaeus Tercentenary: Progress in Invertebrate Taxonomy. Zootaxa 1668. Auckland (New Zealand): Magnolia Press, 107-126.

Fedor M.J., Williamson J.R. 2005: The catalytic diversity of RNAs. Nature Reviews Molecular Cell Biology, 6: 399-412.

JAeger J.A., Turner D.H., Zuker M. 1989: Improved predictions of secondary structures for RNA. Proceedings of the National Academy of Sciences of the United States of America, 86: 7706-7710.

JAIN S.L. 1952: Monogenea of Indian freshwater fishes. II. Thaparocleidus wallagonius n.g. \& n. sp. (subfamily Tetraonchinae) from the gills of Wallagonia attu (BLOCH) from Lucknow. Indian Journal of Helminthology, 4: 43-48.

Jovelin R., Justine J.L. 2001: Phylogenetic relationships within the polyopisthocotylean monogeneans (Platyhelminthes) inferred from partial 28S rDNA sequences. International Journal of Parasitology, 31: 393-401. 
Jow H., Hudelot C., Rattray M., Higgs P.G. 2002: Bayesian phylogenetics using an RNA substitution model applied to early mammalian evolution. Molecular Biology and Evolution, 19: 1591-1601.

Justine J.L., Jovelin R., Neifar R., Mollaret I., Lim L.H.S. et al. 2002: Phylogenetic positions of the Bothitrematidae and Neocalceostomatidae (Monoopisthocotylean Monogeneans) inferred from 28S rDNA sequences. Comparative Parasitology, 69: 20-25.

KJER K.M. 2004: Aligned 18S and insect phylogeny. Systematic Biology 53: 506-514.

KJer K.M., Honeycutt R. 2007: Site specific rates of mitochondrial genomes and the phylogeny of eutheria. BMC Evolutionary Biology, 7: 8-16.

Kimura M. 1980. A simple method for estimating evolutionary rate of base substitutions through comparative studies of nucleotide sequences. Journal of Molecular Evolution, 16: 111-120.

Kruskal J.B., Wish M. 1977: Multidimensional Scaling. Sage Publications, Beverly Hills, CA.

Lim L.H.S., Furtado J.I. 1986: Five new species of ancylodiscoidins (Monogenea: Ancylodiscoidinae) from Notopterus chitala (Hamilton) and Notopterus notopterus (Pallas) in Peninsular Malaysia. Folia Parasitologica, 33: 315-325.

Lim L.H.S., Timofeeva T.A., Gibson D.I., 2001: Dactylogyridean monogeneans of the siluriform fishes of the Old World. Systematic Parasitology, 50: 159-197.

Littlewood D.T.J., Rohde K., Clough K.A. 1998: The phylogenetic position of Udonella (Platyhelminthes). International Journal of Parasitology, 28: 1241-1250.

Malmberg G. 1970: The excretory systems and the marginal hooks as a basis for the systematics of Gyrodactylus (Trematoda, Monogenea). Arkiv for Zoologi Serie, 23: 1-235.

Mollaret I., Jamieson B.G.M., Adlard R.D., Hugall A., Lecointre G. et al. 1997: Phylogenetic analysis of the Monogenea and their relationships with Digenea and Eucestoda inferred from 28S rDNA sequences. Molecular and Biochemical Parasitology, 90: 433-438.

Mollaret I., Jamieson B.G.M., Justine J.L. 2000a: Phylogeny of the Monopisthocotylea and Polyopisthocotylea (Platyhelminthes) inferred from 28S rDNA sequences. International Journal of Parasitology, 30: 171-185.

Mollaret I., Jamieson B.G.M., Justine J.L. 2000b: Phylogenetic position of the monogeneans Sundanonchus, Thaparocleidus, and Cichlidogyrus inferred from 28S rDNA sequences. International Journal of Parasitology, 30: 659-662.

Olson P.D., Cribb T.H., TKach V.V., Bray R.A., Littlewood D.T.J. 2003: Phylogeny and classification of the digenea (Platyhelminthes: Trematoda). International Journal of Parasitology, 33: 733-755.

Olson P.D., Littlewood D.T.J. 2002: Phylogenetics of the Monogenea-evidence from a medley of molecules. International Journal of Parasitology, 32: 233-244.

Paperna I. 1969: Monogenetic trematodes of the fish of the Volta basin and South Ghana. Bulletin du Institute Français d'Afrique Noir, 31: 840-880.

Prasad P.K., Tandon V., Biswal D.K., Goswami L.M., Chatterjee A. 2009. Phylogenetic reconstruction using secondary structures and sequence motifs of ITS2 rDNA of Paragonimus westermani (Kerbert, 1878) Braun, 1899 (Digenea: Paragonimidae) and related species. BMC Genomics, 10(Suppl. 3): S25.

Sharp P.A. 2009: The centrality of RNA. Cell, 136: 577-580. 
Siebert S., Backofen R. 2005: MARNA: multiple alignment and consensus structure prediction of RNAs based on sequence structure comparisons. Bioinformatics, 21: 3352-3359.

Tamura K., Peterson D., Peterson N., Stecher G., Nei M. et al. 2011: MegA5: Molecular Evolutionary Genetics Analysis using Maximum Likelihood, Evolutionary Distance, and Maximum Parsimony Methods. Molecular Biology and Evolution, 28: 2731-2739.

Telford M.J., Wise M.J., Gowri-Shankar V., 2005: Consideration of RNA secondary structure significantly improves likelihood-based estimates of phylogeny: examples from the Bilateria. Molecular Biology and Evolution, 22: 11291136.

Thompson J.D., Higgins D.G., Gibson T.J. 1994: CLUSTAL W: improving the sensitivity of progressive multiple sequence alignment through sequence weighting, positions-specific gap penalties and weight matrix choice. Nucleic Acids Research, 22: 4673-4680.

Voigt O., Erpenbeck D., Wörheide G., 2008: Molecular evolution of rDNA in early diverging Metazoa: First comparative analysis and phylogenetic application of complete SSU rRNA secondary structures in Porifera. BMC Evolutionary Biology, 8: 69 .

von Reumont B., Meusemann K., Szucsich N., Dell'Ampio E., Gowri-Shankar V. et al. 2009: Can comprehensive background knowledge be incorporated into substitution models to improve phylogenetic analyses? A case study on major arthropod relationships. BMC Evolutionary Biology, 9: 119.

Whittington I.D., Deveny M.R., Morgan J.A.T., Chisholm L.A., Adlard R.D. 2004: A preliminary phylogenetic analysis of the Capsalidae (Platyhelminthes: Monogenea: Monopisthocotylea) inferred from large subunit rDNA sequences. Parasitology, 128: 511-519.

Wu X.Y., Chilton N.B., Zhu X.Q., Xie M.Q., Li A.X. 2005: Molecular and morphological evidence indicates that Pseudorhabdosynochus lantauensis (Monogenea: Diplectanidae) represents two species. Parasitology, 130: 669-677.

ZandT F.K. 1924: Fischparasiten des Bodensees. Centralblatt für Bakteriologie und Parasitenkunde I. Abteilung Originale, 92: 225-277.

Zuker M. 1994: Prediction of RNA Secondary Structure by Energy Minimization Computer Analysis of Sequence Data, Part II, AM Griffin \& HG Griffin, Eds, vol. 25. Totowa, NJ: CRC Press, Inc. Chapter 23, 267-294.

Zuker M., Mathews D.H., Turner D.H. 1999: Algorithms and thermodynamics for RNA secondary structure prediction: a practical guide. In BARCiszewsKI, J. and Clark, B.F.C. (eds), RNA Biochemistry and Biotechnology, Kluwer Academic Publications, Dordrecht, The Netherlands: 11-43. 